bition of $\mathrm{HK}$ activity by 2,3-DPG may also have contributed to the decrease in the concentration of G-6-P and other intermediates distal to this step. The magnitude of the increase in the 2,3DPG concentration was probably further enhanced by the increasing plasma $\mathrm{Pi}$ concentration. After the first 10-14 days of life all glycolytic intermediates fell simultaneously. At this time other control mechanisms became operative since glycolytic enzyme activities were also decreasing, as demonstrated by the significant correlation between the decreasing activity of red cell DPGM and corresponding decrease in the red cell 2,3-DPG concentration.

These studies have demonstrated that red cell PFK plays a key regulatory role in postnatal life in lambs. Thus, the fetal lamb can serve as a model for the study PFK activation and inhibition in vivo and the regulation of 2,3-DPG synthesis.

\section{REFERENCES}

1. Bard H, Fouron JC, Grothe AM, Soukini MA, Cornet A 1976 The adaptation of the fetal red cells of newborn lambs to extrauterine life: the role of 2,3diphosphoglycerate and adult hemoglobin. Pediatr Res 10:823

2. Battaglia FC, Behrman RE, Hellegers AE, Battaglia JD 1965 Intracellular hydrogen ion concentration changes during acute respiratory acidosis and alkalosis. J Pediatr 66:737

3. Battaglia FC, McGaughey H, Makowski EL, Meschia G: 1970 Postnatal changes in oxygen affinity of sheep red cells: a dual role of diphosphoglyceric acid. Am J Physiol 219:217

4. Baumann R, Bauer CH, Rathschlag-Shaefer AM 1972 Causes of the postnatal decrease of blood oxygen affinity in lambs. Respir Physiol 15:151

5. Blunt MH, Kitchens JL, Mayson SM, Huisman THJ 1971 Red cell 2,3diphosphoglycerate and oxygen affinity in newborn goats and sheep. Proc Soc Exp Biol Med 138:800

6. Bunn FH 1981 Evolution of mammalian hemoglobin function. Blood 58:189

7. Fiske $\mathrm{CH}$, Subbarow Y 1925 The colorimetric determination of phosphorus. J
Biol Chem 66:375

8. Keitt AS 1969 Hemolytic anemia with impaired hexokinase activity. J Clin Invest 48:1997

9. Lichtman MA, Miller DR 1970 Erythrocyte glycolysis, 2,3-diphosphoglycerate and adenosine triphosphate concentration in uremic subjects: relationship to extracellular phosphate concentration. J Lab Clin Med 76:267

10. Lichtman MA, Miller DR, Cohen J, Waterhouse C 1971 Reduced red cell glycolysis, 2,3-diphosphoglycerate and adenosine triphosphate concentration and increased hemoglobin-oxygen affinity caused by hypophosphatemia. Ann Intern Med 74:562

11. Minakami S, Yoshikawa H 1965 Inorganic phosphate and erythrocyte glycolysis. Biochim Biophys Acta 99:175

12. Noble NA, Cabalum TC, Nathanielsz PW, Tanaka KR 1982 Erythrocyte enzymes in sheep: comparison of activity in fetal, newborn, maternal and non-pregnant ewe erythrocytes. Biol Neonate 41:161

13. Noble NA, Jansen CAM, Nathanielsz PW, Tanaka KR 1983 Mechanism of red cell 2,3-diphosphoglycerate increase in neonatal lambs. Blood 61:920

14. Rapoport S, Guest GM 1938 Changes of organic acid-soluble phosphorus, diphosphoglycerate, adenosine triphosphate, and inorganic phosphorus in blood cells of rats during the development and healing of rickets. J Biol Chem 126:749

15. Rizzo SC, Eckel RE 1966 Control of glycolysis in human erythrocytes by inorganic phosphate and sulfate. Am J Physiol 211:429

16. Rose IA, Warms JVB, O'Connell EL 1964 Role of inorganic phosphate in stimulating the glucose utilization of human red blood cells. Biochem Biophys Res Commun 15:33

17. Srivastava SK, Beutler E 1972 The effect of normal red cell constituents on the activities of red cell enzymes. Arch Biochem Biophys 148:249

18. Travis SF, Kumar SP, Delivoria-Papadopoulos M 1981 Red cell metabolic alterations in postnatal life in term infants: glycolytic intermediates and adenosine triphosphate. Pediatr Res 15:34

19. Travis SF, Kumar SP, Paez PC, Delivoria-Papadopoulos M 1980 Red cell metabolic alterations in postnatal life in term infants: glycolytic enzymes and glucose-6-phosphate dehydrogenase. Pediatr Res 14:1349

20. Travis SF, Sugerman HJ, Ruberg RL, Dudrick SJ, Delivoria-Papadopoulos M Miller LD, Oski FA 1971 Alterations of red cell glycolytic intermediates and oxygen transport as a consequence of hypophosphatemia in patients receiving intravenous hyperalimentation. N Engl J Med 285:763

\title{
Epidermal Growth Factor Binding to Neonatal Mouse Skin Explants and Membrane Preparations-Effect of Triiodothyronine
}

\author{
S. B. HOATH, ${ }^{1}$ J. LAKSHMANAN, AND D. A. FISHER
}

Department of Pediatrics, Harbor-UCLA Medical Center, UCLA School of Medicine, Torrance, California 90509

\begin{abstract}
Daily treatment of newborn Swiss-Webster mice with triiodothyronine (T3, 500 ng/day) increased epidermal growth factor (EGF) content in whole skin (epidermis + dermis). Separation of the epidermis using 0.01 $\mathrm{M}$ dithiothreitol followed by processing for radioimmuno-
\end{abstract}

Received July 20, 1984; accepted October 24, 1984.

Reprint requests Dr. Steven B. Hoath, Department of Pediatrics, University of Cincinnati Medical Center, Mail Location 541, Room 6263, 231 Bethesda Avenue Cincinnati, OH 45267.

This work was supported by Grants HD-04270, HD-07013 from The National Institute of Child Health, and Human Development of The National Institute of Health.

A preliminary report of these findings was presented at the 29th Annual Meeting of the Western Association of Physicians, February 1984.

${ }^{1}$ Current address: Department of Pediatrics, ML 541, University of Cincinnati College of Medicine, Cincinnati, $\mathrm{OH} 45267$. assay measurement reveals levels of EGF 2-to 3-fold higher in epidermis than in whole skin. In vitro flotation of circular skin sections from control and T3 treated neonatal mice in medium containing $\left[I^{125}\right]$ EGF showed increased uptake of label following 5 days of in vivo T3 treatment. Mouse skin membrane preparations exhibit saturable, specific binding of $\left[I^{125}\right]$ EGF. T3 treatment for 5 days in vivo significantly increased EGF binding capacity in skin membrane preparations but did not alter EGF receptor affinity (Kd $4.5 \mathrm{nM}$ ). Protein, RNA, and DNA concentrations were significantly increased in whole neonatal mouse skin following $\mathrm{T3}$ administration. These results suggest one mechanism by which thyroid hormones increase skin EGF concentration is augmentation of skin EGF receptor binding. (Pediatr Res 19: 277-281, 1985) 


\section{Abbreviations}

EGF, epidermal growth factor

T3, triiodothyronine

SMG, submandibular gland

PBS, phosphate buffered saline

BSA, bovine serum albumin

Among the many well known developmental effects of thyroid hormones is the promotion of early incisor eruption and eyelid opening in neonatal rodents $(17,18,28)$. These integumental effects are similar to those produced by EGF (7). Recently, we presented evidence linking hyper- and hypothyroidism in neonatal mice with changes in concentrations of EGF in whole skin (15). These findings suggested mediation of hormone action by modulation of endogenous tissue growth factor levels.

The present report refines our previous study. Levels of immunoassayable EGF in T3 treated and control neonatal mouse epidermis are presented and contrasted with those obtained from whole skin. An effect of in vivo T3 treatment to enhance uptake of $\left[\mathrm{I}^{125}\right] \mathrm{EGF}$ by whole neonatal mouse skin in vitro is described. Membrane binding data are presented suggesting T3 induction of EGF receptor number in skin. Finally, measures are given of total protein, RNA and DNA in the skin of control and T3treated neonatal mice.

\section{MATERIALS AND METHODS}

Preparation of epidermal samples. Newborn Swiss Webster mice were randomly crossfostered into litters of eight pups containing four control (bobbed tails) and four T3-treated animals. Treatments consisted either of $10 \mu \mathrm{l} 0.9 \%$ saline (controls) or $500 \mathrm{ng} \mathrm{T} 3$ in $10 \mu \mathrm{l} 0.001 \mathrm{~N} \mathrm{NaOH}$ given subcutaneously. Injections began on the day of birth (day 0 ) and continued daily for 4 consecutive days. Animals were sacrificed by decapitation $24 \mathrm{~h}$ after the last injection on the 5th postnatal day. The dorsal and upper flank skin was dissected free of subcutaneous tissue, washed in $0.9 \%$ saline, and sections were floated dermal side down on $20 \mathrm{ml}$ of medium in a $60 \times 15 \mathrm{~mm}$ tissue culture dish (Costar Plastics, Cambridge, MA) using the dish cover as a lid. The medium consisted of $0.05 \mathrm{M}$ phosphate buffered saline, $\mathrm{pH}$ 7.3, 5\% glucose, and 0.01 M dithiothreitol DTT (Cal Biochem, La Jolla, CA). After $60 \mathrm{~min}$ of incubation in room air at $23^{\circ} \mathrm{C}$, the skin was carefully removed, placed dermal side down on absorbent paper, and the epidermis gently peeled off as a continuous sheet. The epidermis was washed for $2 \mathrm{~min}$ in $0.9 \%$ saline. Individual epidermal samples weighing 7-15 mg were diluted in $500 \mu$ ice cold $0.05 \mathrm{M}$ PBS containing $0.5 \mathrm{mg} / \mathrm{ml}$ sodium azide. Homogenates were prepared using 20 strokes of a tight-fitting automated glass/Teflon pestle homogenizer. The homogenates were clarified by centrifugation at $30,000 \times g$ for $30 \mathrm{~min}$ at $4^{\circ} \mathrm{C}$ prior to assay. Whole skin sections from the above animals weighing approximately $75 \mathrm{mg}$ were prepared as described previously (15). Total homogenate protein concentrations were determined by the method of Lowry et al (19).

Whole skin $\left[I^{125}\right] E G F$ uptake. Dorsal and ventral skins were dissected from 5-day-old neonatal mice following hormone treatment as described for the epidermal preparations. Skin specimens were placed dermis down on a clean glass plate and circular sections were cut from each specimen using a no. 6 cork borer. Each section, measuring approximately $48 \mathrm{~mm}$ in diameter, was floated in $1 \mathrm{ml} 0.05 \mathrm{M}$ PBS $+5 \%$ glucose in 48-well plastic cluster plates (Costar). Incubations for binding assays were begun by transferring the skin sections to adjacent wells containing 400 $\mu \mathrm{l}$ of the same buffer + approximately $220,000 \mathrm{cpm}\left[{ }^{125}\right] \mathrm{EGF}$ at $23^{\circ} \mathrm{C}$. Sections were floated on the incubation mixture with the epidermis uppermost and dry. The reaction was terminated by swirl-washing the section in $0.9 \%$ saline for $20 \mathrm{~s}$, then blotting away excess water with absorbent paper. The sections were weighed, placed in the bottom of $12 \times 75 \mathrm{~mm}$ polystyrene tubes, and counted in a gamma counter.

Preparation of skin plasma membranes. Preliminary studies were performed on crude skin membrane preparations following the protocol of O'Keefe et al (21). In brief, individual skins from 5-day-old T3-treated and littermate control mice were homogenized 1:10 (w/v) in 0.05 M PBS using a Tekmar Tissumizer (Tekmar Co., Cincinnati, $\mathrm{OH}$ ) at $95 \%$ high speed for $60 \mathrm{sec}$. Samples were spun at $1000 \times g$ at $4^{\circ} \mathrm{C}$ and the fat-free supernatant respun at $40,000 \times g$ for $30 \mathrm{~min}$. The membrane pellet was resuspended in $500 \mu \mathrm{l}$ PBS and respun at $40,000 \times g$. The final pellet was resuspended in $500 \mu \mathrm{l}$ PBS and frozen at $-20^{\circ} \mathrm{C}$ until assay.

Skin plasma membranes were isolated by differential centrifugation according to the method of Hock and Hollenberg (16) for isolating the EGF plasma membrane receptor from human placental tissue. In summary, dorsal skins were homogenized in $0.25 \mathrm{M}$ sucrose and $25 \mathrm{mM}$ Tris- $\mathrm{HCl}, \mathrm{pH} 7.4$. Following the initial Tissumizer disruption, samples were further homogenized with 15 strokes in an automated glass/Teflon pestle apparatus. The homogenate was filtered through nylon mesh and centrifuged at $4^{\circ} \mathrm{C}$ for $10 \mathrm{~min}$ at $600 \times \mathrm{g}$. The supernatant was aspirated and recentrifuged at $10,000 \times g$ for $30 \mathrm{~min}$. The resulting supernatant was made $0.1 \mathrm{M}$ in $\mathrm{NaCl}$ and $0.2 \mathrm{mM}$ in $\mathrm{MgSO}_{4}$, then respun at $50,000 \times g$ for $40 \mathrm{~min}$. The pellet was resuspended in $50 \mathrm{mM}$ Tris- $\mathrm{HCl}, \mathrm{pH} \mathrm{7.6}$, then harvested by recentrifugation a $50,000 \times g$ for $30 \mathrm{~min}$. The final pellet was resuspended in $50 \mathrm{mM}$ Tris- $\mathrm{HCl}$ to yield approximately $1 \mathrm{mg} /$ $\mathrm{ml}$ membrane protein. Protein determinations were performed by the method of Peterson (22) using BSA as standard.

$I^{125} E G F$ binding assay. Mouse EGF was purified from testosterone treated adult male mice by the method of Savage and Cohen (23). EGF was radiolabeled with $\mathrm{I}^{125}$ as previously described. The specific activity of the $\left[\mathrm{I}^{125}\right] \mathrm{EGF}$ employed for binding assays was determined by self-displacement assay of the tracer hormone in a homologous mouse EGF-radioimmunoassay (15).

Typically, measurements of peptide binding were performed with 50-100 $\mu \mathrm{g}$ of membrane protein suspended in $0.05 \mathrm{M}$ PBS, pH 7.3, containing $250 \mu \mathrm{g} \mathrm{BSA}$ in a final reaction volume of 200 $\mu$ l. Binding was initiated in $12 \times 75 \mathrm{~mm}$ polystyrene tubes at $23^{\circ}$ $\mathrm{C}$ by the addition of $220,000 \mathrm{cpm}\left[\mathrm{I}^{125}\right] \mathrm{EGF}$ with and without the presence of $2 \mu \mathrm{g}$ unlabeled EGF. After the designated incubation period the reaction was terminated by diluting the samples with $3 \mathrm{ml}$ ice-cold PBS and passing of the mixture through Whatman glass fiber filters (Whatman, Inc, Clifton, NJ) on a multiple manifold filtration apparatus. The filters were washed with $12 \mathrm{ml}$ cold buffer and radioactivity retained on the filters was counted in a gamma counter.

Biochemical analysis of mouse skin. Approximately $100 \mathrm{mg}$ of dorsal skin (epidermis and dermis) were minced with fine scissors on an ice-cold glass plate. The tissue mince was solubilized $1: 9(\mathrm{w} / \mathrm{v})$ in $2 \mathrm{~N} \mathrm{KOH}$ using a glass/Teflon motor-driven pestle homogenizer at $4^{\circ} \mathrm{C}$. The homogenate was then centrifuged at $25,000 \times g$ for $20 \mathrm{~min}$ and transferred to $12 \times 75 \mathrm{~mm}$ glass tubes. The pellets were rehomogenized in $0.5 \mathrm{ml}$ of $2 \mathrm{~N}$ $\mathrm{KOH}$ at $4^{\circ} \mathrm{C}$ and recentrifuged as described above. The supernatants were combined and processed as follows: aliquots equal to $50 \mathrm{mg}$ tissue were treated with excess perchloric acid to precipitate macromolecules. The tubes were kept in ice for 20 min and centrifuged at $500 \times g$ for $30 \mathrm{~min}$. The supernatants were discarded and the pellets were resuspended in $2 \mathrm{ml}$ ice-cold $0.2 \mathrm{~N}$ perchloric acid and centrifuged as described above. The supernatants were discarded and the washing procedure was repeated twice.

The pellets were resuspended using glass rods in $2 \mathrm{ml} 0.3 \mathrm{~N}$ $\mathrm{KOH}$ and incubated at $37^{\circ} \mathrm{C}$ for $16-18 \mathrm{~h}$ for hydrolysis and extraction of RNA. The DNA and protein were reprecipitated with perchloric acid to a final concentration of $10 \%$ followed by centrifugation at $500 \times g$ for $30 \mathrm{~min}$. The pellets were washed once with $0.2 \mathrm{~N}$ perchloric acid, recentrifuged and the superna- 
tants combined with the previous supernatants containing the RNA hydrolysate. The precipitate was then digested with $10 \%$ perchloric acid at $90^{\circ} \mathrm{C}$ for $30 \mathrm{~min}$ to extract the DNA hydrolysis products. The samples were cooled and centrifuged at $1000 \times g$ for $30 \mathrm{~min}$. The supernatants was used for DNA estimation as described by Giles and Myers (12). The protein pellet was dissolved in $0.1 \mathrm{~N} \mathrm{NaOH}$ and protein concentration measured by the method of Lowry et al. (19) using BSA dissolved in $0.1 \mathrm{~N}$ $\mathrm{NaOH}$ as standard. RNA was determined by ultraviolet absorption at $260 \mathrm{~nm}$ according to the method of Fleck and Munro (10). Calf thymus DNA (Sigma) and Escherichia coli RNA (Sigma) were used as standards.

\section{RESULTS}

Epidermal EGF levels. Postnatal treatment of neonatal mice with T3 significantly elevated endogenous EGF levels in epidermis and whole skin (Fig. 1). Absolute values for epidermal EGF (mean $\pm \mathrm{SEM}$ ) were $159 \pm 10$ and $307 \pm 25 \mathrm{pg}$ EGF/mg protein for control and T3 groups, respectively $(p<0.001)$. Whole skin values from the same animals were $70 \pm 6$ versus $93 \pm 10 \mathrm{pg}$ / $\mathrm{mg}$ protein $(p<0.05)$. Experimental groups consisted of 16 control and $16 \mathrm{~T} 3$-treated littermates drawn from a total of five litters. Equal numbers of control and treated pups were taken from each litter. No significant difference in mean body weight of control and treated pups was noted. (All statistical analyses were with Student's $t$ test.)

Serial dilutions of mixed epidermal supernatant from T3treated and control mouse pups (range 2.5-200 $\mu \mathrm{l}$ ) were tested for parallelism with the EGF standard curve in the RIA system. After log-logit transformation, the slopes of the regression lines (supernatant vs standard curve) were statistically similar. Recovery of standard EGF (50-100 pg) added to $25 \mu \mathrm{l}$ epidermal supernatant (equivalent to 50 pg EGF) was assessed in quadruplicate specimens. Mean $( \pm$ SEM) recovery was $92 \pm 2 \%$.

$\left[I^{125}\right] E G F$ uptake in whole skin. Dorsal skin from 5-day-old T3-treated mice exhibited an increased rate of uptake of $\left[\mathrm{I}^{125}\right]$ EGF from the medium when floated for up to $150 \mathrm{~min}$ in room air at $23^{\circ} \mathrm{C}$ (Fig. $2 \mathrm{~B}$ ). Values shown are normalized to $100 \mathrm{mg}$ wet weight of tissue. Mean weights of individual skin sections were similar in the two groups (control $=48.1 \pm 1.2 \mathrm{mg}$; T3 = $45.7 \pm 1.3 \mathrm{mg} ; p>0.05)$. Ventral skin sections exhibited a similar pattern of T3-induced label uptake, but total values were approximately 1.5 times greater than those for dorsal skin at 60 min (data not shown). In contrast, dorsal skin from 4-day-old mouse pups showed a small but nonsignificant increase in $\left[\mathrm{I}^{125}\right]$ EGF uptake following T3 treatment (Fig. 2A). Ventral skin uptake was significantly greater than dorsal skin uptake in both groups $(p<0.01)$.

$\left[I^{125}\right] E G F$ membrane binding. Specific binding of $\left[{ }^{125}\right] \mathrm{EGF}$ was increased in crude skin membrane preparations from 5-dayold T3-treated mouse pups versus littermate controls (Fig. 3).

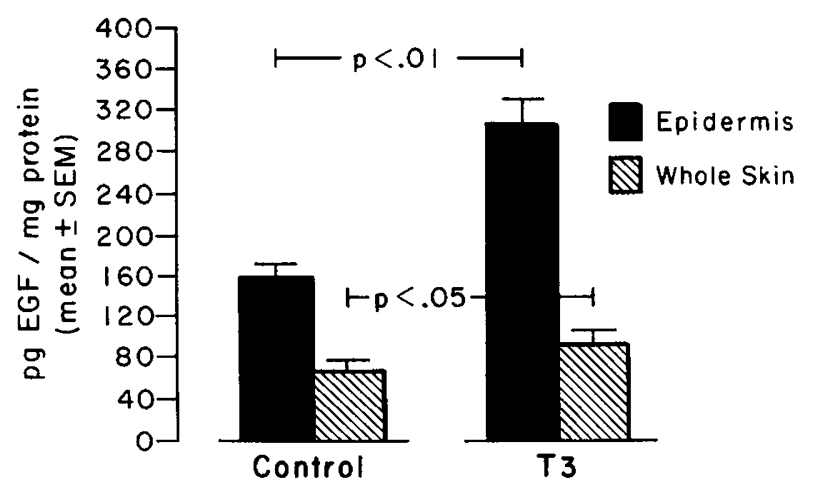

Fig. 1. Effect of $\mathrm{T} 3$ on EGF content in neonatal mouse epidermis and whole skin. Values represent 16 control pups versus T3-treated littermates sacrificed on the 5th postnatal day. Significance testing by Student's $t$ test.

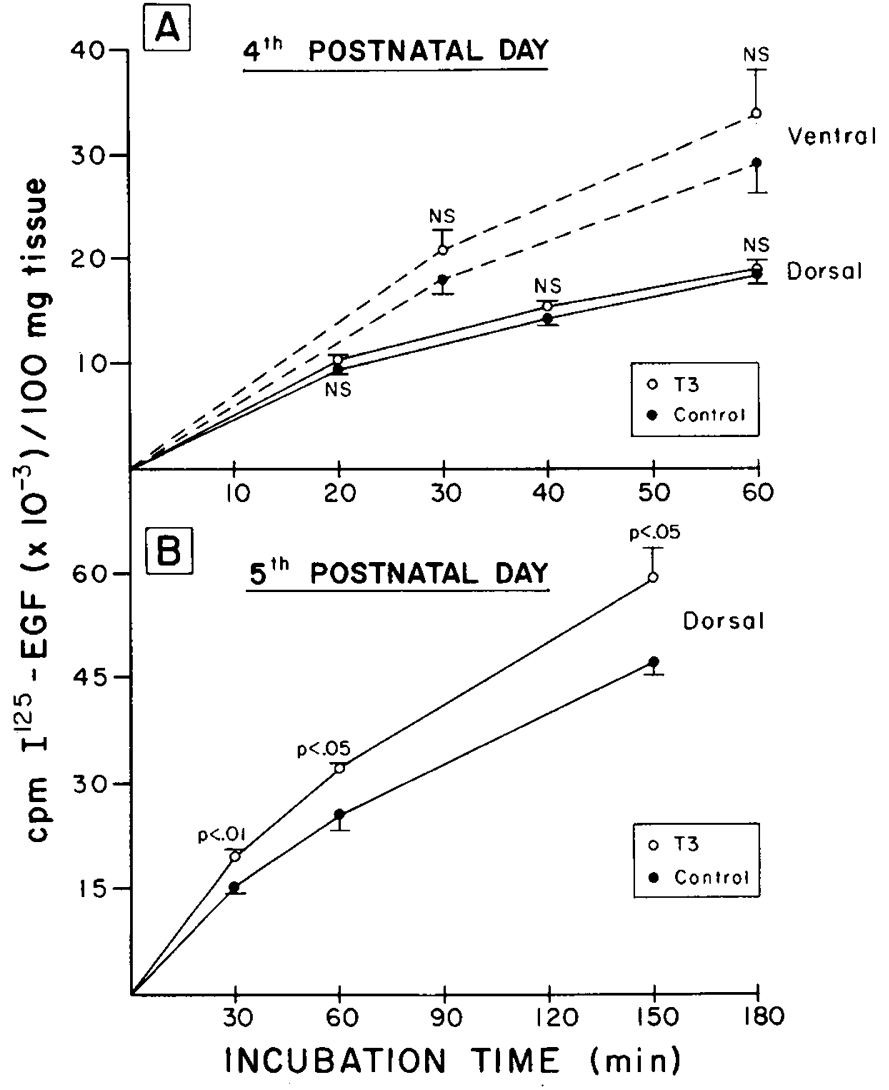

Fig. 2. Effect of in vivo $\mathrm{T} 3$ treatment on in vitro uptake of $\left[\mathrm{I}^{125}\right] \mathrm{EGF}$ by neonatal mouse skin $(A)$ uptake of label by ventral and dorsal mouse skin on the 4th postnatal day. Each skin section incubated at $23^{\circ} \mathrm{C}$ in $400 \mu \mathrm{l}$ buffer containing $100000 \mathrm{cpm}\left[\left[^{125}\right]\right.$ EGF $(360 \mathrm{pg})$. See text for details $(B)$ uptake by dorsal mouse skin on the 5 th postnatal day. Similar conditions to above except sections incubated with $200,000 \mathrm{cpm}\left[\mathrm{I}^{125}\right]$ EGF. All time points represent the mean \pm SEM of six to eight individual animals.

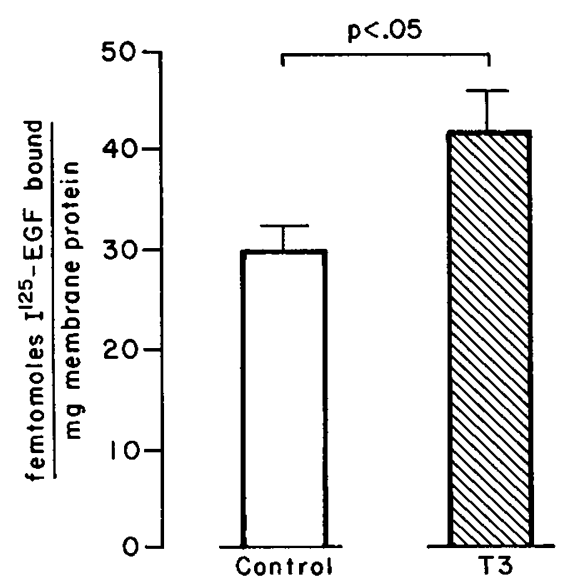

Fig. 3. Increase in $\left[\mathrm{I}^{125}\right] \mathrm{EGF}$ specific binding to crude skin membrane preparations following T3 treatment. Approximately $100 \mu \mathrm{g}$ membrane protein were incubated for $30 \mathrm{~min}$ at $23^{\circ} \mathrm{C}$ in a total reaction volume of $250 \mu \mathrm{l}$ containing $280,000 \mathrm{cpm}\left[\mathrm{I}^{125}\right] \mathrm{EGF}$ (1000 pg). Specimens were assayed in duplicate and corrected for nonspecific binding by subtraction of counts bound in the presence of $3 \mu \mathrm{g}$ unlabeled EGF. Results are given as means \pm SEM. Significance testing was performed using Student's 2-tailed $t$ test for unpaired observations.

Each specimen represents ventral skin pooled from two animals for a total of 12 animals in each group. Mean body weight was similar in the two groups of animals. Equilibrium binding curves for dorsal skin membrane preparations (Fig. 4) showed a similar 


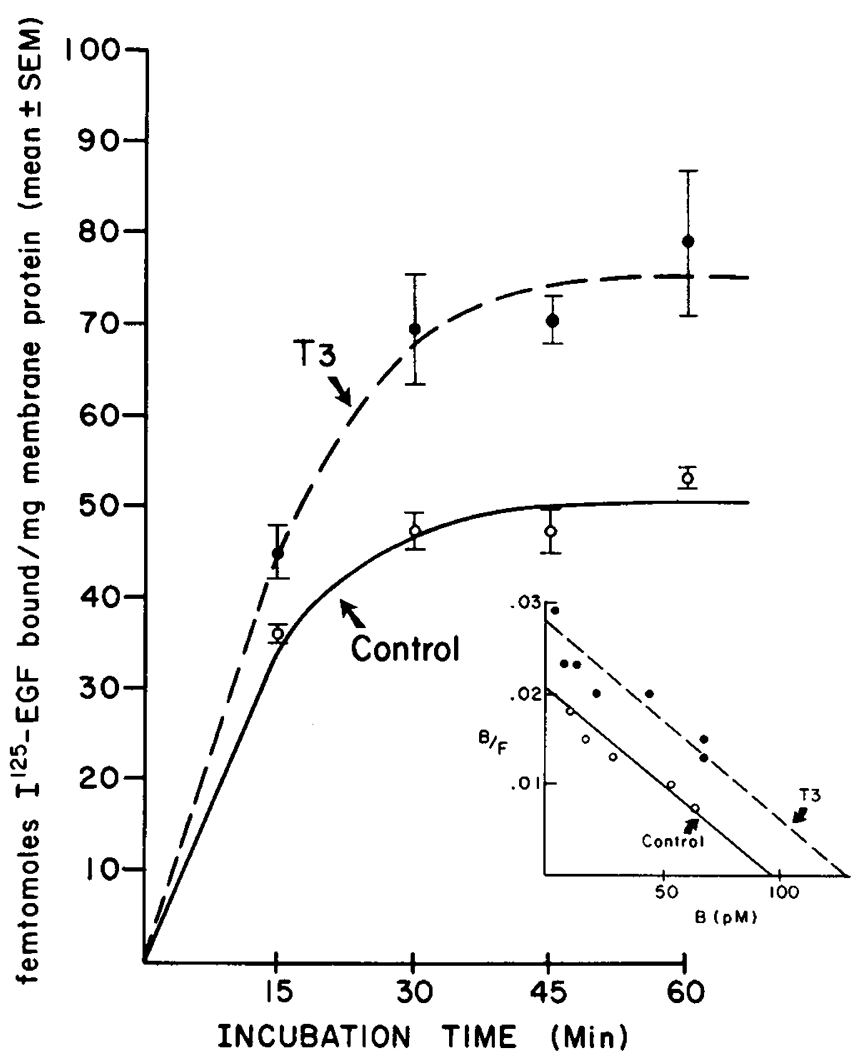

Fig. 4. Binding of $\left[I^{125}\right] E G F$ to skin plasma membrane preparations. Membranes were prepared according to the method of Hock and Hollenberg (16) using dorsal skin samples pooled from 16 control and 16 T3-treated 5-day-old neonatal mice. Approximately $40 \mu \mathrm{g}$ membrane protein were incubated for $30 \mathrm{~min}$ at $23^{\circ} \mathrm{C}$ with $225,000 \mathrm{cpm}\left[I^{125}\right] \mathrm{EGF}$ $(690 \mathrm{pg})$ in a total reaction volume of $225 \mu \mathrm{l}$. Results are means \pm SEM of triplicate determinations corrected for nonspecific binding as described in text. The inset shows Scatchard analysis of subsequent equilibrium binding data using increasing amounts of $\left[\mathrm{I}^{125}\right]$ EGF. Analysis was performed under the assumption of linear correlation (correlation coefficients $=-0.90$ and -0.95 for $\mathrm{T} 3$ and control groups, respectively).

Table 1. Effect of T3 on macromolecular content of neonatal mouse skin*

\begin{tabular}{llll}
\hline & Protein $(\mathrm{mg})$ & RNA $(\mu \mathrm{g})$ & DNA $(\mu \mathrm{g})$ \\
\hline Control & $3.6 \pm 0.1$ & $223 \pm 9$ & $143 \pm 9$ \\
T3 & $4.3 \pm 0.2 \dagger$ & $285 \pm 13 \dagger$ & $242 \pm 11 \dagger$ \\
\hline
\end{tabular}

* Values are means \pm SEM and are normalized to $100 \mathrm{mg}$ wet weight of whole skin.

$\dagger p<0.01$.

increase in binding in the T3-treated group with a plateau reached by approximately 30-min incubation. Scatchard analysis of subsequent equilibrium binding data (Fig. 4 , inset) is consistent with a single order of binding sites with a Kd of $4.5 \mathrm{nM}$. Maximum binding capacities for control and T3-treated membranes were 0.59 and $0.70 \mathrm{pm}\left[\mathrm{I}^{125}\right] \mathrm{EGF} / \mathrm{mg}$ membrane protein, respectively. Binding was improved using freshly isolated membrane preparations with $>10 \%$ specific binding achieved in the T3-treated group using $50 \mu \mathrm{g}$ membrane protein; no difference in equilibrium binding of $\left[\mathrm{I}^{125}\right] \mathrm{EGF}$ was noted between ventral and dorsal skin membrane preparations within either group (data not shown).

Effect of T3 on macromolecular constituents of whole skin. Table 1 shows the effect of T3 treatment on protein, DNA, and
RNA content of whole skin of 6-day-old mouse pups. Injections were begun on the day of birth (day 0 ) and continued daily until sacrifice on postnatal day 6 approximately $24 \mathrm{~h}$ after the last injection. Groups consisted of two litters containing six pups each. T3 treatment resulted in significant elevations in all constituents studied. In contrast to the previous groups, T3 produced a significant reduction in body weight in this experiment from $4.9 \pm 0.3 \mathrm{~g}$ for controls to $3.7 \pm 0.2 \mathrm{~g}(p<0.01)$. EGF levels measured in dorsal skin homogenates from the same experimental animals increased following T3 treatment from $81 \pm 4$ to 290 $\pm 30 \mathrm{pg} / 100 \mathrm{mg}$ wet weight $(p<0.01)$.

\section{DISCUSSION}

The present results confirm our earlier observation that $\mathrm{T} 3$ treatment of neonatal mice increases skin EGF concentrations. Moreover we confirm earlier reports by Frati et al. (11) (using an EGF radioreceptor system in adult mice) that epidermal levels of EGF exceed dermal levels several fold. As in whole skin, postnatal treatment with T3 augments EGF levels in epidermis. Previously, we speculated as to the possible sources of this EGF and showed that maternal sialoadenectomy did not significantly decrease skin EGF levels in mouse pups on the 2nd postnatal day (17), obviating an important maternal salivary gland source (15). Newborn mouse submandibular glands contain little EGF compared to adults (14). Another source of EGF in the suckling animal is maternal milk which has been shown in both humans and rodents to contain significant quantities of EGF $(2,3,25)$. Finally, local (paracrine) growth factor production and action, as with somatomedin (8), is an unproven possibility.

Supporting milk as a possible source of skin EGF is the observation that oral administration of EGF elicits eyelid opening in neonatal mice (7). Recent data by Thornburg et al. (27) suggests that labeled mouse EGF given orally to suckling rats undergoes molecular processing and structural alteration during absorption with subsequent accumulation of the label in skin. Although it is known that antibodies and other macromolecules are absorbed by the neonatal rat intestine during the first 18 days of life $(5,6)$, the extent of EGF absorption is not clear.

To assess skin binding of EGF we first measured the uptake of $\left[\mathrm{I}^{125}\right] \mathrm{EGF}$ by small skin sections floated in vitro under simple assay conditions (Fig. 2B). Carpenter et al. (4) had reported that iodinated EGF was biologically equipotent to unlabeled EGF as assessed by the acceleration of eyelid opening in vivo. In this study, in vivo T3 treatment markedly enhanced labeled EGF uptake by skin. We observed, however, that treatment for less than 5 days produced inconsistent results (Fig. $2 A$ ). In earlier studies measuring immunoassayable EGF levels in skin (15), we also observed a lack of effect of thyroid hormone in the early (day 2) postnatal period. These findings suggest a postnatal delay of several days in the onset of EGF-related thyroid hormone responsiveness in skin.

In order to examine whether the increased uptake of labeled EGF by whole skin in vitro was a specific receptor-related event, membranes were prepared from whole skin by two different methods $(16,21)$. In both preparations, we observed approximately 1.5 -fold greater EGF binding activity/mg protein in membranes from the T3-treated animals. Scatchard analysis (Fig. 3) suggested that the increase in binding was due to increased binding capacity rather than increased receptor affinity (24). Green et al. (13) have presented data in rats showing an inverse relation between postnatal age and EGF receptor number in isolated epidermal basal cells. Although our data do not allow correlation between binding activity and cell number, we observed that T3 treatment increased macromolecular constituents of neonatal mouse skin including protein, RNA, and DNA at 6 days of age (Table 1). Exogenous EGF produces similar elevations at 5 days postnatal age (1).

Recently, Mukku (20) reported that thyroid hormone increases 
EGF receptor levels in adult rat liver. The present study supports these observations and shows that the developing mouse responds to thyroid hormone with increased levels of endogenous EGF receptors in a known EGF target organ, the skin. Thus, one mechanism for modulation of developmental events by thyroid hormones is the modulation of growth factor receptors.

\section{REFERENCES}

1. Angeletti PU, Salvi ML, Ohesanow RL, Cohen S 1964 Azion del "Epidermal Growth Factor" sulla sintesi di acidi nucleici e proteine dell' epitelio cutaneo. Experientia 20:146-148

2. Bynny RL, Orth DN, Cohen S, Doyne ES 1974 Epidermal growth factor: effects of androgens and adrenergic agents. Endocrinology 95:776-782

3. Carpenter $G$ (1980) Epidermal growth factor is a major growth-promoting agent in human milk. Science 210:198-199

4. Carpenter G, Lembach KJ, Morrison MM, Cohen S 1975 Characterization of the binding of $\mathrm{I}^{125}$-labeled epidermal growth factor to human fibroblasts. J Biol Chem 250:4297-4304

5. Clarke RM, Hardy RN 1969 An analysis of cessation of uptake of macromolecular substances by the intestine of the young rat ("closure"). $\mathrm{J}$ Physiol Lond 204:127-134

6. Clarke RM, Hardy RN 1969 The use of polyvinyl pyrrolidone K.60 in the quantitative asessment of the uptake of macromolecular substances by the intestine of the young rat. J Physiol Lond 204:113-125

7. Cohen S, Taylor JM 1974 Epidermal growth factor: chemical and biological characterization. Rec Prog Horm Res 30:533-550

8. D'Ercole AJ, Applewhite GT, Underwood LE 1980 Evidence that somatomedin is synthesized by multiple tissues in the fetus. Dev Biol 75:315-328

9. Epstein EH Jr, Munderloh NJ, Fukyyama K 1979 Dithiothreitol separation of newborn rodent dermis and epidermis. J Invest Dermatol 73:207-210

10. Fleck A, Munro HN 1962 The precision of ultraviolet absorption measurements in the Schmidt-Thannhauser procedure for nucleic acid estimation. Biochem Biophys Acta 551:571-583

11. Frati L, Conci G, Sbaraglia G, Venza Teti D, Corelli I 1976 Levels of epidermal growth factor in mice tissues measured by a specific radioreceptor assay. Life Sci 18:905-912

12. Giles KN, Myers A 1965 An improved diphenylamine method for the estimation of deoxyribonucleic acid. Nature 206:93
13. Green MR, Basketter DA, Couchman JR, Rees DA 1983 Distribution and number of epidermal growth factor receptors in skin is related to epithelial cell growth. Dev Biol 10:506-512

14. Hoath SB, Lakshmanan J, Fisher DA 1983 Differential hormone response of epidermal growth factor concentration in the developing mouse: synergism of triiodothyronine and dexamethasone in epidermal maturation. Life Sci $32: 2709-2716$

15. Hoath SB, Lakshmanan J, Scott SM, Fisher DA 1983 Effect of thyroid hormones on epidermal growth factor concentration in neonatal mouse skin. Endocrinology 112:308-314

16. Hock RA, Hollenberg MD 1980 Characterization of the receptor for epidermal growth factor-urogastrone in human placenta membranes. J Biol Chem 255:10731-10736

17. Karnofsky D, Cronkite EP 1939 Effect of thyroxine on eruption of teeth in newborn rats. Proc Soc Exp Biol 40:568-570

18. Khamsi F, Eayrs JT 1966 A study of the effects of thyroid hormones on growth and development. Growth 30:143-156

19. Lowry OH, Rosebrough NJ, Farr AL, Randall RJ 1951 Protein measurement with the Folin phenol reagent. J Biol Chem 193:265-275

20. Mukku VR 1984 Regulation of epidermal growth factor receptor levels by thyroid hormone. J Biol Chem 259:6543-6547

21. O'Keefe F, Hollenberg MD, Cuatrecasas P 1974 Epidermal growth factorcharacteristics of specific binding in membranes from liver, placenta and other target tissues. Arch Biochem Biophys 164:518-526

22. Peterson GL 1977 A simplification of the protein assay method of Lowry et al. which is more generally applicable. Anal Biochem 83:346-356

23. Savage CR Jr, Cohen S 1972 Epidermal growth factor and new derivative. Rapid isolation procedures and biological and chemical characterization. $J$ Biol Chem 247:7609

24. Scatchard G 1949 The attraction of protein for small molecules and ions. Ann NY Acad Sci 51:660-672

25. Shing YW, Klagsbrun M 1984 Human and bovine milk contain different sets of growth factors. Endocrinology 115:273-282

26. Starkey RH, Orth DN 1977 Radioimmunoassay of human epidermal growth factor (urogastrone). J Clin Endocrinol Metab 45:1144-1153

27. Thornburg W, Matrisian L, Magun B, Koldovsky O 1984 Gastrointestinal absorption of epidermal growth factor in suckling rat. Am J Physiol 246:G80-G85

28. Walker DG 1957 An assay of the skeletogenic effect of L-triiodothyronine and its acetic acid analogue in immature rats. Johns Hopkins Hosp Bull 101:101114

\title{
Intrauterine Growth-Retarded Rat Pups Show Increased Susceptibility to Pulmonary $\mathrm{O}_{2}$ Toxicity
}

\author{
LEE FRANK, PAMELA L. LEWIS, AND TERESA GARCIA-PONS \\ Pulmonary Research Division and Oak Asthma Research and Treatment Facility, University of Miami School of \\ Medicine, Miami, Florida 33101
}

\begin{abstract}
We used a nutritional deprivation model to produce intrauterine growth-retarded (IGR) rat pups (birth weight $=\sim 75 \%$ of normal). The IGR newborns evidenced a marked reduction in tolerance to $>95 \% \mathrm{O}_{2}$ exposure: 10 day survival $=10 / 47(21 \%)$ versus $18 / 36(50 \%)$ for control pups, and $\mathrm{LT}_{50}=7.2$ days versus 10 days for controls $(p$ $<0.01$ ). Various lung parameters at birth and during $\mathrm{O}_{2}$
\end{abstract}

Received July 20, 1984; accepted October 24, 1984

Reprint requests: Dr. Lee Frank, Pulmonary Research R120, University of Miami, School of Medicine, P.O. Box 016960, Miami, FL 33101.

Supported by NIH Grant HL 26029 and NHLBI Research Career Development Award HL01230. exposure were examined to try to define why prenatal undernutrition should compromise the survival of IGR rats in hyperoxia. We found decreased lung glutathione peroxidase and glucose-6-phosphate dehydrogenase activity (with normal superoxide dismutase and catalase levels) in the IGRs at birth; decreased lung disaturated phosphatidylcholine content (even more markedly decreased in 1day premature pups); and decreased lung surface area/body weight. These factors and other features of newborn IGRs reported in the literature may help to explain how prenatal undernutrition compromises postnatal tolerance to prolonged high- $\mathrm{O}_{2}$ exposure. (Pediatr Res 19: 281-286, 1985) 